\title{
Prevalence of Cytogenetic Abnormalities and FMR1 Gene Premutation in a Portuguese Population with Premature Ovarian Insufficiency
}

\author{
Prevalência de Anomalias Citogenéticas e da Pré- \\ Mutação do Gene FMR1 numa População Portuguesa \\ com Insuficiência Ovárica Prematura
}

Ana Raquel NEVES $\square^{1,2}$, Ana Sofia PAIS ${ }^{1,2}$, Susana Isabel FERREIRA ${ }^{3}$, Vera RAMOS ${ }^{1}$, Maria João CARVALHO ${ }^{1,2}$, Alexandra ESTEVINHO ${ }^{4}$, Eunice MATOSO ${ }^{4}$, Fernanda GERALDES ${ }^{1}$, Isabel MARQUES CARREIRA ${ }^{3}$, Fernanda ÁGUAS ${ }^{1}$ Acta Med Port 2021 Sep;34(9):580-585 - https://doi.org/10.20344/amp.13490

\section{ABSTRACT}

Introduction: Chromosome abnormalities contribute to about $10 \%$ of cases of premature ovarian insufficiency. Most are associated with X chromosome. Fragile mental retardation 1 (FMR1) gene premutation has an estimated prevalence of $1 \%-7 \%$ in sporadic cases and up to $13 \%$ in familial cases. Our aim was to describe the clinical characteristics, cytogenetic and FMR 1 testing of a Portuguese population with premature ovarian insufficiency.

Material and Methods: Women diagnosed with premature ovarian insufficiency in a Portuguese tertiary centre were retrospectively analysed. Data were retrieved from electronic medical records including clinical characteristics, cytogenetic and FMR1 testing. The main outcome measures were the prevalence of chromosome abnormalities and FMR1 premutation in a Portuguese population with premature ovarian insufficiency.

Results: Ninety-four patients were included, with a median age at menopause of 36 years. The prevalence of chromosome abnormalities was $16.5 \%(14 / 85)$ and most were $\mathrm{X}$ chromosome related $(78.6 \%, \mathrm{n}=11)$. The prevalence of $F M R 1$ premutation was $6.7 \%(6 / 90)$. The prevalence of karyotypic abnormalities or FMR1 premutation did not differ significantly between familial and sporadic cases. Neither chromosome abnormalities nor FMR1 premutation influenced age at menopause or follicle stimulating hormone levels at diagnosis in premature ovarian insufficiency patients.

Discussion: This is the first study describing the clinical characteristics and both cytogenetic and FMR1 testing in a Portuguese population with premature ovarian insufficiency. The rate of chromosome abnormalities in our sample was higher than in other populations, while the prevalence of FMR1 premutation was similar to previous reports.

Conclusion: Our results underline the importance of genetic screening in premature ovarian insufficiency patients in both etiological study and genetic counselling.

Keywords: Chromosome Abnormalities; Cytogenetic Analysis; Fragile X Mental Retardation Protein; Premature Ovarian Insufficiency

\section{RESUMO}

Introdução: As anomalias cromossómicas contribuem para 10\% dos casos de insuficiência ovárica prematura estando maioritariamente associadas ao cromossoma X. A pré-mutação do gene fragile mental retardation 1 (FMR1) tem uma prevalência estimada de $1 \%-7 \%$ nos casos esporádicos e até $13 \%$ nos casos familiares. O nosso objetivo foi descrever as características clínicas e a análise citogenética e do gene FMR1 de uma população Portuguesa com insuficiência ovárica prematura.

Material e Métodos: Análise retrospetiva das mulheres com o diagnóstico de insuficiência ovárica prematura vigiadas num hospital terciário Português. Recolha de dados através do processo médico eletrónico incluindo características clínicas, análise citogenética e análise do gene FMR1. Os desfechos principais foram a prevalência de anomalias cromossómicas e da pré-mutação FMR1 numa população Portuguesa com insuficiência ovárica prematura.

Resultados: Foram incluídas 94 doentes, com uma mediana de idade de menopausa de 36 anos. A prevalência de anomalias cromossómicas foi $16,5 \%(14 / 85)$ e a maioria estavam relacionadas com o cromossoma $X(78,6 \%, n=11)$. A prevalência da pré-mutação FMR1 foi de 6,7\% (6/90). A prevalência de anomalias cromossómicas ou pré-mutação FMR1 não diferiu entre casos esporádicos e familiares. Nem as anomalias cromossómicas nem a pré-mutação FMR1 influenciaram a idade de menopausa ou os níveis da hormona estimulante dos folículos aquando do diagnóstico na população com insuficiência ovárica prematura.

Discussão: Este é o primeiro estudo a descrever as características clínicas e a análise citogenética e do gene FMR1 numa população Portuguesa com insuficiência ovárica prematura. A prevalência de anomalias cromossómicas na nossa amostra foi superior à descrita para outras populações, enquanto a prevalência da pré-mutação FMR1 foi semelhante à descrita em estudos anteriores.

Conclusão: Os nossos resultados sublinham a importância do rastreio genético em doentes com insuficiência ovárica prematura, quer no estudo etiológico, quer no aconselhamento genético.

Palavras-chave: Análise Citogenética; Anomalias Cromossómicas; Insuficiência Ovárica Prematura; Proteína do X Frágil de Retardo Mental

\footnotetext{
1. Department of Gynecology. Centro Hospitalar e Universitário de Coimbra. Coimbra. Portugal.

2. University Clinic of Gynecology. Faculty of Medicine. University of Coimbra. Clinical Academic Center of Coimbra. Coimbra. Portugal.

3. Cytogenetics and Genomics Laboratory. Faculty of Medicine. University of Coimbra. Polo Ciências da Saúde. Coimbra. Portugal.

4. Cytogenetics Laboratory. Department of Medical Genetics from the Pediatric Hospital. Centro Hospitalar e Universitário de Coimbra. Coimbra. Portugal.

$\triangle$ Autor correspondente: Ana Raquel Neves. anaraquel.Ineves@gmail.com

Recebido: 23 de janeiro de 2020 - Aceite: 09 de setembro de 2020 - First published: 29 de outubro de 2020 - Online issue published: 01 de setembro de 2021 Copyright $\odot$ Ordem dos Médicos 2021
} 


\section{INTRODUCTION}

Premature ovarian insufficiency (POI) is defined as the loss of ovarian function before the age of 40 and affects approximately $1 \%$ of women. ${ }^{1}$ Clinically, patients may present with primary or secondary amenorrhea, or with olygomenorrhea. ${ }^{1}$ Several factors have been recognized as causes of $\mathrm{POI}$, such as genetic factors, previous chemo- or radiotherapy, bilateral ovarian surgery, autoimmune or infectious diseases. ${ }^{1-3}$ In most cases, however, the underlying cause will remain unknown.

In the last decades, an increasing interest has been drawn to the genetic causes of POI. ${ }^{4-6}$ Chromosome abnormalities are known to be present in $10 \%-13 \%$ of patients with $\mathrm{POI}$ and most are associated with the $\mathrm{X}$ chromosome. ${ }^{4,7,8}$ Numerous karyotypic abnormalities have been reported, ranging from $\mathrm{X}$ chromosome deletions, $\mathrm{X}$-autosome translocations or $\mathrm{X}$-isochromosomes to numerical defects. ${ }^{4,9}$ $\mathrm{X}$-monosomy, both with and without mosaicism, has been associated with an accelerated follicular atresia. ${ }^{4}$ Previous studies have reported that $47, \mathrm{XXX}$ patients are also at risk for $\mathrm{POI}$, with a prevalence varying between $1.5 \%$ and $3.8 \%$. The exact mechanism is still unclear but an association with autoimmune diseases or a meiotic disturbance caused by an extra X chromosome have been proposed. . 7,10 In 1973 , Sarto et al defined a $X$ chromosome critical region from Xq13-Xq21 to Xq23-q27. ${ }^{11}$ The implication of this region in translocations or deletions was associated with POI. Multiple studies have corroborated this finding. ${ }^{4}$

The fragile mental retardation 1 (FMR1) gene is the strongest genetic association with POI. ${ }^{6}$ The FMR1 premutation (FMR1-PM) has a prevalence of 1:130 - 1:250 in the female population. ${ }^{5,12}$ Carriers of premutated alleles, with 55 - 200 CGG repeats, are known to have a risk of developing $\mathrm{POI}$ as high as $34 \% .^{13,14} \mathrm{An}$ association between the number of CGG repeats and the development of $\mathrm{POI}$ has been reported, although the number of repeats associated with the highest risk is still a matter of debate..$^{15-17}$ Contrary to what has been reported in the past, intermediate alleles (45 - 54 CGG repeats) do not seem to be associated with POI. ${ }^{18}$

Carriers of FMR1-PM are not only at risk of developping $\mathrm{POI}$, but also have an increased risk of fragile-X-associated tremor/ataxia syndrome (FXTAS).,19 This is a late onset neurodegenerative disorder, characterized by gait ataxia, dementia and intention tremor, which occurs in male carriers of FMR1-PM. The penetrance of symptoms increases with age, affecting more than one third of patients over 50 years of age and exceeding $50 \%$ for men aged $70-90$ years. Females are also affected although to a lesser extent. ${ }^{19}$

Another reason to test for FMR1-PM is the increased risk of expanding to the full length mutation (over 200 CGG repeats) in the offspring, leading to the Fragile $X$ Syndrome (FXS). This risk is directly associated with the number of the premutation carrier CGG repeats, increasing significantly with more than $65-70$ repeats. ${ }^{20}$

These figures highlight the importance of the genetic characterization of these patients, both at the chromosomal and molecular level. This will contribute to a better understanding of the biological mechanisms associated with POI. Moreover, this knowledge will allow for an evaluation of their family risk of developing $\mathrm{POI}$ or having a fragile $\mathrm{X}$ or FXTAS descendent, identifying family members candidates for genetic evaluation, genetic counseling or prenatal diagnosis. In this regard, a multidisciplinary approach envolving gynecologists, obstetricians, geneticists and neurologists is of paramount importance in the correct counselling of these patients.

It is known that population characteristics, such as ethnicity, may affect $\mathrm{POI}$ prevalence and its genetic contribution. ${ }^{1}$ Therefore, our aim was to describe both cytogenetic abnormalities and FMR1 tests in a Portuguese population with $\mathrm{POI}$.

\section{MATERIAL AND METHODS \\ Study design}

Our group carried out a retrospective study regarding patients with the diagnosis of $\mathrm{POI}$ who attended their first visit in a tertiary university-affiliated hospital between January 2010 and December 2018. The study was performed in accordance with the 2013 Helsinki Declaration and with approval of the Institutional Ethics Committee (reg. 010-2020). Since the study involved completely anonymous data extraction from electronic medical records, patient consent was not required. The inclusion criteria were: primary or secondary idiopathic amenorrhea for at least four months in women under 40 years old and two serum follicle stimulating hormone (FSH) measurements over $25 \mathrm{mUl} / \mathrm{mL}$ obtained at least one month apart. Patients with conditions known to induce POI (previous chemo- or radiotherapy, ovarian surgery and autoimmune diseases) were excluded. Patients with typical Turner syndrome stigmata were also ruled out. Family history of POI was considered when a history of first or second-degree relatives with $\mathrm{POI}$ was present. Family history of Fragile $X$ syndrome was validated when a medical report confirming the diagnosis was available.

Electronic medical records were reviewed for gynecological and obstetric history (age at menarche and menopause, gravidity and parity, previous miscarriages and menstrual pattern), family history of $\mathrm{POI}$ and fragile $\mathrm{X}$ syndrome and laboratory results (plasma serum FSH and estradiol levels at diagnosis, cytogenetic analysis and FMR1 test).

\section{FSH and estradiol measurements}

Plasma serum levels of estradiol and FSH were measured using a commercial chemiluminescence array (CMIA) using the Architect analyser (Abbot Diagnostics, Spain).

\section{Cytogenetic analysis}

Chromosomal analysis was performed on metaphases obtained from $72 \mathrm{~h}$ phytohemagglutinin (PHA) stimulated peripheral blood lymphocyte cultures according to standard procedures. Analysis of GTG-banded chromosomes was 
done at a resolution of 700 bands per haploid genome, according to the International System for Human Cytogenetic Nomenclature (ISCN) 2016. ${ }^{21}$ A minimum of 30 cells were counted to rule out mosaicism, the common occurrence of age related sex chromosome losses and/or gains was considered before reporting sex chromosome mosaicism. ${ }^{22,23}$

\section{FMR1 testing}

Genomic DNA was extracted from peripheral blood lymphocytes using Jetquick blood and cell culture DNA Midi Spin kit (Genomed, Löhne, Germany) and DNA concentration and purity were evaluated using a NanoDrop1000 Spectrophotometer (Thermo Scientific, Waltham, USA). FMR1 gene CGG repeat number was determined by conventional PCR using primers $\mathrm{C}$ and $\mathrm{F}$ described by Fu et al and by Triplet Repeat Primed PCR (TP PCR) using Asuragen AmplideX ${ }^{\circledR}$ FMR1 PCR Kit (Asuragen, Austin, USA), as previously described by Ferreira et al. ${ }^{24,25}$

\section{Statistical analysis}

Statistical analysis was performed using SPSS Statistics, Version 23.0 (IBM Corp., Armonk, NY, USA). Categorical variables were compared using the Fisher's exact test according to the Cochrane rules. Quantitative non-normal variables were expressed as median (interquartile range) and the non-parametric Mann-Whitney $U$ test was used for distribution comparisons. All tests were 2 tailed, and $p<$ 0.05 was considered statistically significant.

\section{RESULTS}

\section{Clinical characteristics}

A total of 94 patients enrolled the study. Patients' gynecological and family history is shown in Table 1 . Median age at menopause was 36.0 (6.0) years. The majority of patients reported secondary amenorrhea $(95.7 \%, n=90)$.

Obstetric history was unavailable in four patients. Overall, the nulliparity rate was $40.0 \%(36 / 90)$ and $18.9 \%$ (17/90) of the patients had a history of previous spontaneous miscarriage.

Twenty-three patients presented a family history of POI.

Table 1 - Patients' baseline characteristics

\begin{tabular}{lc}
\hline \multicolumn{2}{l}{ Obstetric and gynecological history } \\
\hline Age at menarche (years) & $12.0(3.0)$ \\
Primary amenorrhea & $4 / 94(4.3 \%)$ \\
Nulligravida & $31 / 90(34.4 \%)$ \\
Nullipara & $36 / 90(40.0 \%)$ \\
Previous miscarriage & $17 / 90(18.9 \%)$ \\
Age at menopause (years) & $36.0(6.0)$ \\
FSH at diagnosis (IU/L) & $79.0(43.9)$ \\
Estradiol at diagnosis (pg/mL) & $20.0(10.0)$ \\
Family history & \\
POI & $23 / 94(24.4 \%)$ \\
Fragile X syndrome & $2 / 94(2.1 \%)$ \\
\hline
\end{tabular}

The prevalence of primary amenorrhea was $4.3 \%(1 / 23)$ in familial cases and $4.2 \%(3 / 71)$ in sporadic POI patients. A family history of fragile $X$ syndrome was present in 2 patients. None of the cases with family history of fragile $X$ syndrome presented with primary amenorrhea.

No statistically significant difference was found between the median $\mathrm{FSH}$ at diagnosis in patients with primary versus secondary amenorrhea [64.9 (56.0) vs 80.0 (39.0) IU/L, $p=$ 0.392 , Mann Whitney test].

\section{Chromosomal abnormalities}

Due to missing data, the karyotype was analysed in 85 patients (Table 2).

An abnormal karyotype was observed in 16.5\% $(n=14)$, of which $78.6 \%(n=11)$ involved the $X$ chromosome. The most common abnormality was $\mathrm{X}$ chromosome mosaicism, which was found in $50.0 \%$ of our cohort (7/14). The four patients with primary amenorrhea presented a normal karyotype.

No statistically significant differences were found regarding age at menopause [35.5 (7.8) vs 36.0 (6.0) years, $p=0.691$, Mann Whitney test] or FSH at diagnosis [83.0 (62.0) vs 78.1 (32.0) IU/L, $p=0.415$, Mann Whitney test] between patients with $(n=14)$ or without $(n=71)$ an abnormal karyotype.

Also, no statistically significant difference was found regarding the prevalence of karyotypic abnormalities between the 23 patients with a family history of POI $(8.7 \%, n=2)$ and those without $(19.4 \%, \mathrm{n}=12)(p=0.333$, Fisher's exact test).

\section{FMR1 testing}

Due to missing data, FMR1 analysis was performed in 90 patients (Table 3). FMR1-PM was present in $6.7 \%$

Table 2 - Karyotyping

\begin{tabular}{ll}
\hline Normal $(46, \mathrm{XX})$ & $\mathbf{7 1 / 8 5}(83.5 \%)$ \\
\hline Abnormal & $14 / 85(16.5 \%)$ \\
\hline
\end{tabular}

\section{$X$ chromosome related}

- 46,X,del(X)(q25 q26).ish del(X)(DXYS61-)

- 46,X,del(X).ish del(X)(pter-q22.2)(DXS28-)

- 46,X,t(X;8)(q24;q24.22)

$-47, X X X$

- $\operatorname{mos} 45, X[2] / 46, X X[28] . n u c$ ish(DXZ1X1)[4/110]

$-\operatorname{mos} 45, X[1] / 47, X X X[1] / 48, X X X X[1] / 46, X X[47]$

- $\operatorname{mos} 45, X[3] / 47, X X X[1] / 46, X X[26]$

- $\operatorname{mos} 45, X[3] / 47, X X X[1] / 46, X X[26]$

- $\operatorname{mos} 45, X[3] / 47, X X X[1] / 46, X X[16]$

$-\operatorname{mos} 47, X X X[3] / 45, X[1] / 46, X X[26]$

- $\operatorname{mos} 47, X X X[2] / 45, X[1] / 46, X X[32]$

Non-X chromosome related

- $\operatorname{mos} 47, X X,+21[2] / 46, X X[38]$

- 45,XXder(13;14)(q10;q10)

- 47,XX,+mar.ishder(14/22)(D14Z1/D22Z1+,D22S75-) 
Table 3 - Number of CGG repeats in FMR1 testing

\begin{tabular}{ll}
\hline Normal alleles & $\mathbf{8 2}$ patients/90 $(91.1 \%)$ \\
\hline$<29$ & 62 \\
29 & 18 \\
30 & 53 \\
31 & 19 \\
$32-44$ & 19 \\
\hline Intermediate zone alleles & $\mathbf{2}$ patients/90 $(2.2 \%)$ \\
\hline 53 & 1 \\
54 & 1 \\
\hline Premutation alleles & 6 patients/90 $(6.7 \%)$ \\
\hline 58 & 1 \\
60 & 2 \\
69 & 1 \\
80 & 1 \\
82 & 1 \\
\hline
\end{tabular}

$(n=6)$. The most frequent CGG number of repeats was 30 $(n=53)$, followed by $31(n=19)$ and $29(n=18)$.

None of the four patients with primary amenorrhea presented the FMR1-PM.

No significant difference was found between patients with and without FMR1-PM concerning age at menopause [38.0 (1.8) vs 36.0 (6.0) years, $p=0.092$, Mann Whitney test] or FSH levels at diagnosis [84.7 (63.0.) vs 77.7 (40.0) IU/L, $p=0.340$, Mann Whitney test].

There was a higher prevalence of FMR1-PM in patients with a family history of POI, but this difference was not statistically significant $[13.0 \%$ (3/23), vs 4.5\% (3/67), $p=0.176$, Fisher's exact test].

Both patients with a family history of $X$ fragile syndrome carried premutated alleles $[(30,60)$ and $(35,58)]$.

\section{DISCUSSION}

This is the first study describing the clinical characteristics and both cytogenetic and FMR1 testing in a Portuguese population with $\mathrm{POI}$.

The median age at menopause in our population was 36 years, similar to the results published by Murray et al in a UK population. ${ }^{26}$ In an Italian study, Baronchelli et al also reported a mean age at menopause of 34 years. ${ }^{27}$ However, in this study the authors considered patients with menopause before the age of 45 years. ${ }^{27}$ Janse et al described a median age at menopause of 32 years in a POI Dutch population. ${ }^{28}$ Lower ages at menopause have been reported in POI non-European populations, varying between 24 and 30 years. ${ }^{7,8,29-31}$ Although more studies are needed to consolidate this data, the available evidence seems to point towards a higher age at menopause in European populations with POI. This is in line with previous reports which suggest differences regarding age of natural menopause in different ethnic groups. ${ }^{32}$ Despite the controversy regarding race/ethnicity per se as a factor that influences age at menopause, a higher educational level, the prolonged use of oral contra- ceptives and a higher baseline weight seem to be associated with a higher age at natural menopause. ${ }^{32,33}$ The exact mechanism behind these associations is not completely understood. Although no epidemiological studies have been performed in POI populations, we hypothesize that these factors may also contribute to our results.

The prevalence of primary amenorrhea in our population was $4.3 \%(95 \% \mathrm{Cl} 1.6 \%-11.0 \%)$, which is lower than in other populations $(13.2 \%-51.0 \%)$. ${ }^{7,8,28,29,31,34}$ We hypothesized that the fact that our department attends to predominantly adult patients might have contributed to this bias.

The rate of previous spontaneous miscarriage was $18.9 \%(95 \% \mathrm{Cl} 12.0 \%-28.5 \%)$, which is higher than the findings reported by Allen et al and Jansel et al in a POI population $(5.0 \%-13.9 \%)$, but similar to the expected rate in the general population. ${ }^{15,28,35}$

The prevalence of chromosomal abnormalities in our population was $16.5 \%$ (95\% Cl $9.9 \%-26.1 \%)$. Most studies report a prevalence of karyotypic abnormalities varying between $9 \%$ and $14 \%$. $^{7,8,27,28,31,34}$ However, a higher prevalence, between $21 \%$ and $32 \%$, has also been reported in Tunisian, American, Chilean and Turkish populations. ${ }^{29,36-38}$ Similarly to what has been previously published, most karyotypic abnormalities were $X$ chromosome related. ${ }^{7,8,28,29}$ In our population, in accordance with the results of Lakahl et al and Janse et al, the most frequent were mosaic numerical $X$ chromosome abnormalities. ${ }^{28,31}$ Other authors reported $X$ chromosome structural abnormalities as being the most frequent. $7,8,27,29$ Regarding $X$ chromosome structural abnormalities, in our sample, all cases involved the $\mathrm{Xq}$, which is in agreement with previous studies and with the critical regions previously defined for the development of POI (Xq13-Xq21 and Xq23-Xq27).,7,11 Two patients presented Robertsonian translocations, which have also been previously reported in POI patients, although the autosomal role in POI remains unexplained. ${ }^{4,7}$ Finally, one patient, who was referred to our department due to secondary amenorrhea, presented one autosomal mosaic involving trisomy 21 in two different cell lines $[47, X X,+21(2) / 46, X X(38)]$. Being a mosaic, we cannot predict the presence of the trisomy in other tissues and a causal effect with POI cannot be excluded, since women with Down syndrome have a higher chance of suffering from POI. ${ }^{39,40}$

Despite the fact that previous studies found a higher prevalence of chromosome abnormalities in patients with primary amenorrhea than in patients with secondary amenorrhea, ${ }^{8,29,31}$ none of the cases with primary amenorrhea presented karyotypic abnormalities in our study. Most certainly, the small size of the primary amenorrhea subgroup ( $\mathrm{n}$ $=4$ ) was underpowered to detect these differences. Similarly to what has been previously described, no difference was found regarding the prevalence of karyotypic abnormalities in familial and sporadic cases. ${ }^{8,31}$

The prevalence of FMR1-PM in our sample was $6.7 \%$ (96\% Cl $3.0 \%-14.2 \%)$, similar to what has been previously described in non-Asian populations. ${ }^{1,29}$ In Asian populations, the prevalence seems to be lower $(0.5 \%-1.5 \%) .{ }^{30}$ 
This is in line with a previous study involving almost 135000 women from an unselected pan-ethnic cohort, which also reported a lower incidence of FMR1-PM in Asian patients. ${ }^{41}$ In accordance with other studies, the prevalence was higher in familial cases of $\mathrm{POI}(13.6 \%$ vs $4.5 \%))^{5,14,26}$ The fact that this difference was not statistically significant in our sample may also be attributed to the small sample size. The number of CGG repeats has emerged as a possible predictor of risk and severity of FMR1-related POI. Despite still being a matter of debate, 80 - 100 repeat alleles seem to confer the highest risk. ${ }^{15,16}$ In our sample, among the six patients with FMR1-PM, only two presented alleles in the high-risk zone (respectively, 80 and 82 ).

The most frequent number of CGG repeats has been reported as $32,{ }^{4}$ while in our sample the most frequent allele was 30 . This probably reflects population related variations, which account for the importance of the genetic characterization of these patients on a population level. Considering that fragile $X$ syndrome is the result of the expansion of the number of CGG repeats when transmitted from mother to offspring, the fact that both patients with family history of fragile $X$ syndrome presented FMR1-PM $[(30,60)$ and $(35,58)]$ was an expected finding. In accordance with the findings by Bouali et al, all patients with FMR1-PM presented with secondary amenorrhea. ${ }^{29}$

\section{CONCLUSION}

Taking into account the prevalence of chromosomal abnormalities and FMR1-PM in our cohort, these results demonstrate the importance of genetic screening for patients with $\mathrm{POI}$ and add new data on the different phenotypic and genotypic patterns of this disorder in different populations. We highlight the higher prevalence of chromosome abnormalities in our Portuguese cohort. Chromosomal studies and FMR1 testing not only provide an etiological explanation for the POI patient, but they also bear important information for both reproductive and genetic counselling, both for the couple and other relatives. Taking into account the extra-reproductive risks conferred by FMR1-PM, namely FXS and FXTAS, the importance of a multidisciplinary approach for these patients, involving gynaecologists, obstetricians, neurologists and medical geneticists should not be disregarded.

\section{AUTHORS CONTRIBUTION}

ARN: Concept and design of the work; literature review; data acquisition, analysis and interpretation; draft of the paper.

ASP, SIF, AE, EM: Data acquisition and interpretation; critical review of the manuscript; approval of the final version.

VR, FA: Data interpretation; critical review of the manuscript; approval of the final version.

MJC: Concept and design of the work; data acquisition and interpretation; critical review of the manuscript; approval of the final version.

FG, IMC: Concept and design of the work; data interpretation; critical review of the manuscript; approval of the final version.

\section{PROTECTION OF HUMANS AND ANIMALS}

The authors declare that the procedures were followed according to the regulations established by the Clinical Research and Ethics Committee and to the 2013 Helsinki Declaration of the World Medical Association.

\section{DATA CONFIDENTIALITY}

The authors declare having followed the protocols in use at their working center regarding patients' data publication.

\section{COMPETING INTERESTS}

The authors have declared that no competing interests exist.

\section{FUNDING SOURCES}

This research did not receive any specific grant from funding agencies in the public, commercial, or not-for-profit sectors.

\section{REFERENCES}

1. European Society for Human Reproduction and Embryology (ESHRE) Guideline Group on POI, Webber L, Davies M, Anderson R, Bartlett J, Braat D, Cartwright B, et al. ESHRE Guideline: management of women with premature ovarian insufficiency. Hum Reprod. 2016;31:926-37.

2. Coccia ME, Rizzello F, Mariani G, Bulletti C, Palagiano A, Scarselli G. Ovarian surgery for bilateral endometriomas influences age at menopause. Hum Reprod. 2011;26:3000-7.

3. Silva C, Yamakami L, Aikawa N, Araujo D, Carvalho J, Bonfá E. Autoimmune primary ovarian insufficiency. Autoimmun Rev. 2014;13:427-30.

4. Qin Y, Jiao X, Simpson JL, Chen ZJ. Genetics of primary ovarian insufficiency: New developments and opportunities. Hum Reprod Update. 2015;21:787-808.

5. Rossetti R, Ferrari I, Bonomi M, Persani L. Genetics of primary ovarian insufficiency. Clin Genet. 2017;91:183-98.

6. Greene AD, Patounakis G, Segars JH. Genetic associations with diminished ovarian reserve: A systematic review of the literature. J Assist Reprod Genet. 2014;31:935-46.

7. Jiao X, Qin C, Li J, Qin Y, Gao X, Zhang B, et al. Cytogenetic analysis of 531 Chinese women with premature ovarian failure. Hum Reprod. 2012;27:2201-7.

8. Kalantari H, Madani T, Zari Moradi S, Mansouri Z, Almadani N, Gourabi $\mathrm{H}$, et al. Cytogenetic analysis of 179 Iranian women with premature ovarian failure. Gynecol Endocrinol. 2013;29:588-91.

9. Liu J, Cox L. Primary ovarian insufficiency: an update. Int J Womens Health. 2014;6:235.

10. Goswami R, Goswami D, Kabra M, Gupta N, Dubey S, Dadhwal V. Prevalence of the triple $X$ syndrome in phenotypically normal women with premature ovarian failure and its association with autoimmune thyroid disorders. Fertil Steril. 2003;4:1052-4.

11. Sarto $G$, Therman E, Patau K. X inactivation in man: a woman with $t(X q-$ $-; 12 q+)$. Am J Hum Genet. 1973;3:262-70.

12. Hagerman P. The fragile $X$ prevalence paradox. J Med Genet. 2008;45:498-9.

13. Utine GE, Şimşek-Kiper PÖ, Akgün-Doğan Ö, Ürel-Demir G, Alanay Y, Aktaş $D$, et al. Fragile $x$-associated premature ovarian failure in a large 
Turkish cohort: Findings of Hacettepe Fragile X Registry. Eur J Obstet Gynecol Reprod Biol. 2018;221:76-80.

14. Wittenberger MD, Hagerman RJ, Sherman SL, McConckie-Rosell A, Welt C, Rebar RW, et al. The FMR1 premutation and reproduction. Fertil Steril. 2007;87:456-65.

15. Allen E, Sullivan A, Marcus M, Small C, Dominguez C, Epstein MP, et al. Examination of reproductive aging milestones among women who carry the FMR1 premutation. Hum Reprod. 2007;22:2142-52.

16. Sullivan AK, Marcus M, Epstein MP, Allen EG, Anido AE, Paquin JJ, et al. Association of FMR1 repeat size with ovarian dysfunction. Hum Reprod. 2005;20:402-12.

17. Spath M, Feuth T, Smits A, Yntema HG, Braat DD, Thomas CM, et al. Predictors and risk model development for menopausal age in fragile $\mathrm{x}$ premutation carriers. Genet Med. 2011;13:643-50.

18. Schufreider A, McQueen DB, Lee SM, Allen R, Uhler M, Davie J, et al. Diminished ovarian reserve is not observed in infertility patients with high normal CGG repeats on the fragile X mental retardation 1 (FMR1) gene. Hum Reprod. 2015;30:2686-92.

19. Jacquemont S, Hagerman RJ, Hagerman PJ, Leehey MA. Fragile-X syndrome and fragile $\mathrm{X}$-associated tremor / ataxia syndrome : two faces of FMR1. Lancet Neurol. 2007;6:45-55.

20. Yrigollen C, Durbin-Johnson B, Gane L, Nelson DL, Hagerman R Hagerman PJ, et al. AGG interruptions within the maternal FMR1 gene reduce the risk of offspring with fragile $X$ syndrome. Genet Med. 2012;14:729-36.

21. McGowan-Jordan J, Simons A, Schmid M, editors. An international system for human cytogenomic nomenclature. Basel: S. Karger; 2016.

22. Gardner R, Sutherland G, Shaffer L. Chromosome abnormalities and genetic counselling. 4 ${ }^{\text {th }}$ ed. Oxford: Oxford University Press; 2012.

23. Guttenbach M, Koschorz B, Bernthaler U, Grimm T, Schmid M. Sex chromosome loss and aging: in situ hybridisation studies on human interphase nuclei. Am J Hum Genet. 1995;57:1143-50.

24. Fu Y, Kuhl D, Pizzuti A, Pieretti M, Sutcliffe JS, Richards S, et al. Variation of the CGG repeat at the fragile $X$ site results in genetic instability: resolution of the Sherman paradox. Cell. 1991;67:1047-58.

25. Ferreira SI, Pires LM, Ferrão J, Sá J, Serra A, Carreira IM. Mosaicism for FMR1 gene full mutation and intermediate allele in a female foetus: a postzygotic retraction event. Gene. 2013;527:421-5.

26. Murray A, Schoemaker MJ, Bennett CE, Ennis S, MacPherson JN, Jones $\mathrm{M}$, et al. Population-based estimates of the prevalence of FMR1 expansion mutations in women with early menopause and primary ovarian insufficiency. Genet Med. 2014;16:19-24.

27. Baronchelli S, Conconi D, Panzeri E, Bentivegna A, Redaelli S, Lissoni $\mathrm{S}$, et al. Cytogenetics of premature ovarian failure: an investigation on
269 affected women. J Biomed Biotechnol. 2011;2011:20-2.

28. Janse F, Knauff E, Niermeijer M, Eijkemans MJ, Laven JS, Lambalk CB, et al. Similar phenotype characteristics comparing familial and sporadic premature ovarian failure. Menopause. 2010;17:758-65.

29. Bouali N, Hmida D, Mougou S, Bouligand J, Lakhal B, Dimessi S, et al. Analysis of FMR1 gene premutation and $X$ chromosome cytogenetic abnormalities in 100 Tunisian patients presenting premature ovarian failure. Ann Endocrinol. 2015;76:671-8.

30. Guo T, Qin Y, Jiao X, Li G, Simpson JL, Chen ZJ. FMR1 premutation is an uncommon explanation for premature ovarian failure in Han Chinese. PLoS One. 2014;9:6-10.

31. Lakhal B, Braham R, Berguigua R, Bouali N, Zaouali M, Chaieb M, et al. Cytogenetic analyses of premature ovarian failure using karyotyping and interphase fluorescence in situ hybridization (FISH) in a group of 1000 patients. Clin Genet. 2010;78:181-5.

32. Gold EB. The timing of the age at which natural menopause occurs. Obs Gynecol Clin N Am. 2011;38:425-40.

33. Gold EB, Crawford SL, Avis NE, Crandall CJ, Matthews KA, Waetjen LE, et al. Original contribution factors related to age at natural menopause : longitudinal analyses from SWAN. Am J Epidemiol. 2013;178:70-83.

34. Portnoï MF, Aboura A, Tachdjian G, Bouchard P, Dewailly D, Bourcigaux $\mathrm{N}$, et al. Molecular cytogenetic studies of Xq critical regions in premature ovarian failure patients. Hum Reprod. 2006;21:2329-34.

35. National Collaborating Centre for Women's and Children's Health (UK). Ectopic pregnancy and miscarriage: ectopic pregnancy and miscarriage: diagnosis and initial management in early pregnancy of ectopic pregnancy and miscarriage. 2012. [accessed 2019 Jan 15]. Available rom: https://www.nice.org.uk/guidance/cg154/.

36. Ceylaner G, Altinkaya S, Mollamahmutoglu L, Ceylaner S. Genetic abnormalities in Turkish women with premature ovarian failure. Int $J$ Gynaecol Obstet. 2010;110:122-4.

37. Castillo S, López F, Tobella L, Salazar S, Daher V. The cytogenetics of premature ovarian failure. Rev Chil Obs Ginecol. 1992;57:341-5.

38. Rebar R, Connolly $\mathrm{H}$. Clinical features of young women with hypergonadotropic amenorrhea. Fertil Steril. 1990;53:804-10.

39. Romualdi D, Proto C, De Cicco S, Immediata V, Barone C, Romano C et al. Low AMH levels as a marker of reduced ovarian reserve in young women affected by Down's syndrome. Menopause. 2016;23:1247-51.

40. Parizot E, Dard R, Janel N, Vialard F. Down syndrome and infertility: what support should we provide? J Assist Reprod Genet. 2019;36:1063 1067

41. Owens KM, Dohany L, Holland C, DaRe J, Mann T, Settler C, et al. FMR1 premutation frequency in a large, ethnically diverse population referred for carrier testing. Am J Med Genet Part A. 2018;176:1304-8. 